Article

\title{
Five Decades of Structural and Compositional Changes in Managed and Unmanaged Montane Stands: A Case Study from South-East Europe
}

\author{
Srđan Keren ${ }^{1, *}(\mathbb{D})$, Milan Medarević ${ }^{2}$, Snežana Obradović ${ }^{2}$ and Brane Zlokapa ${ }^{3}$ \\ 1 Department of Biometry and Forest Productivity, Faculty of Forestry, University of Agriculture in Krakow, \\ al. 29-Listopada 46, 31-425 Krakow, Poland \\ 2 Faculty of Forestry, University of Belgrade, 11000 Belgrade, Serbia; milan.medarevic@sfb.bg.ac.rs (M.M.); \\ snezana.obradovic@sfb.bg.ac.rs (S.O.) \\ 3 Faculty of Forestry, University of Banja Luka, 78000 Banja Luka, Bosnia and Herzegovina; \\ brane.zlokapa@sf.unibl.org \\ * Correspondence: s.keren@ur.krakow.pl; Tel.: +48-535323482
}

Received: 3 July 2018; Accepted: 4 August 2018; Published: 7 August 2018

\begin{abstract}
The recent research has indicated that restoration of old-growth attributes such as large-sized living trees and snags contributes to sustaining biodiversity on the landscape level. The extent to which these attributes are restored, maintained, or diminished by total salvage logging, selection silviculture, and strict protection has been partly investigated in the past. However, studies examining the influence of partial salvage logging are largely absent. Thus, we compared long-term structural and compositional changes in three montane beech-fir-spruce stands in Serbia that were exposed to different management regimes for five decades (partial salvage logging, selection silviculture, and strict protection). Tree species composition of partly salvaged stand and selection stand significantly differed from that in the adjacent unmanaged stand. However, the diameter distributions of compared stands often exhibited the same structural forms in certain periods, despite the greater share of large-size trees in the unmanaged stand. The study indicated that managing for old-growth attributes such as large trees may be possible by applying not only rotated sigmoid and negative exponential structures, but also the increasing- $q$ diameter structure as high basal areas in studied beech-fir-spruce stands did not impair the ingrowth of young trees when conifers dominated the upperstory. The study further revealed that partial salvaging may serve as a sound alternative to promoting old-growth attributes such as large veteran trees and snags.
\end{abstract}

Keywords: stand structure; partial salvage logging; old-growth; selection silviculture; restoration

\section{Introduction}

Strictly protected or otherwise created areas of old-growth forests make up a very small percentage of the overall forest area worldwide [1-3]. Therefore, strict protection alone is considered to be insufficient for sustaining old-growth attributes and species diversity over larger landscapes $[2,4,5]$. Parviainen et al. [2] indicated that the more management activities follow natural processes in production forests, the less there is a need for the total conservation of forests. In this context, single-tree selection silviculture has been classified as a close-to-nature system, but this approach aims at choosing mostly those natural processes that best achieve management goals such as target species composition, optimal growth, or high-quality timber [6]. Therefore, some authors took a step further by proposing a more comprehensive natural forest management that, in addition to sustainable diameter structure, natural regeneration and tree species composition, also includes the presence of large living veteran trees and large snags $[4,7,8]$. However, the problem of the lack of old-growth 
attributes was not acknowledged until relatively recently [9]. As a consequence, most studies focusing on the restoration of old-growth characteristics very rarely cover longer time spans [10]. For this reason, knowledge on restoration of old-growth attributes is still lacking.

The importance of rotated sigmoid, negative exponential, and increasing- $q$ structural forms $[4,11-13]$ lies in the fact that they can support high basal areas and allow adequate recruitment of large trees without endangering the overall tree-size demographic equilibrium. Moreover, the creation of stand structures with the full-range of tree sizes, including live veteran trees and standing dead trees, is crucial for sustaining biodiversity [14]. However, such structures are deficient in many areas, as forests have been mostly used for commercial reasons [15]. Nevertheless, despite high demands for wood products, many countries are now making an effort to restore some of the extinct old-growth attributes such as snags and large-sized living trees as they represent indispensible habitats for a large number of species $[4,7]$.

Information about the structural and compositional changes of forests that are subject to different harvesting regimes may serve as a guideline for restoring old-growth conditions in managed forests, that is, at the larger landscape scale [10]. For management purposes, it is thus vital to investigate and understand how forest ecosystems respond to different silvicultural activities. Several studies in North America have investigated the restoration of old-growth attributes in managed forests through the application of a structural complexity enhancement approach and selection systems $[4,8,16,17]$ as well as extended rotation forestry $[18,19]$. In contrast, there have been only few similar studies in Europe $[10,13,14]$. Moreover, long-term studies of structural dynamics and compositional changes have been rare for many ecologically and economically important forest types around the world [19].

The diversity of forest structures and natural tree species composition in most parts of Europe was greatly reduced by clear-cutting after the late 1700s [14,20,21]. European beech (Fagus sylvatica L.; hereafter beech) was especially affected, whereas conifers such as Norway spruce (Picea abies L. Karst; hereafter spruce) and Scots pine (Pinus sylvestris L.) were favored. However, forestry activities in some countries have recently led to increased structural and compositional diversity [22,23]. This indicates that the paradigm of close-to-nature silviculture has become partly accepted in practice, at least with respect to certain structural attributes related to live trees.

Since forests in South-East Europe are often located on limestone and steep slopes, and thus susceptible to erosion, the history of forest management in this part of Europe was mostly characterized by gradual conversion of old-growth forests to managed uneven-aged forests, usually by the application of selection silviculture [24]. This approach may have contributed to better conservation of trees having diameters at breast height ( $\mathrm{dbh}$ ) between $50 \mathrm{~cm}$ and $80 \mathrm{~cm}$ [25]. However, the policies in South-East Europe related to conserving standing dead trees (snags) and very large living trees $(>80 \mathrm{~cm} \mathrm{dbh}$ ) have focused mostly on strictly protected areas.

A mixture of beech, spruce, and silver fir (Abies alba Mill.; hereafter fir) is often the dominant forest type in the mountainous regions of Europe [26]. In Serbia, mixed stands composed of these species cover relatively small areas $[27,28]$ because both fir and spruce in this country are close to the southern edge of their natural range, which makes them more susceptible to climate changes and disturbance events. For this reason, these stands were given special attention and were often thoroughly monitored. The basis of our research consists of long-term data from partly salvaged stand, selection stand, and an unmanaged stand on Tara mountain in western Serbia. Salvage logging may have both positive and negative effects on forest ecosystems [29]. Recently, however, especially negative effects are studied after all damaged trees are removed following large or medium natural disturbances [30-33]. In the Dinaric forests, such events occur also occasionally, but small-scale gaps are predominant, whereas the wind tends to be the major disturbance agent [34]. In this study, partial salvage logging was conducted in response to low severity disturbances rather than stand-replacing disturbance (details are provided in the Section 2.1).

While the studies on the effects of selection silviculture and strict protection have been moderately frequent, the studies on the influence of partial salvage logging on stand structural characteristics 
have been almost nonexistent. Consequently, the major goals of the present study were to (i) compare whether three differently managed beech-fir-spruce stands (partial salvaging, selection management, and strict protection) differed across five decades with respect to the form of the diameter distribution and tree species composition, (ii) investigate how different management regimes influenced the recruitment of large-sized living trees, and (iii) test for differences between partly salvaged stand and unmanaged stand in terms of the density and basal area of snags.

\section{Materials and Methods}

\subsection{Study Area and Management Regimes}

The study area is located in the Tara National Park (NP) in western Serbia. The Tara mountain is situated in the range of Dinaric Mountains between $43^{\circ} 51^{\prime}$ and $43^{\circ} 57^{\prime} \mathrm{N}$ and $17^{\circ} 03^{\prime}$ and $17^{\circ} 11^{\prime} \mathrm{E}$. Different types of management are applied in this area, including the selection system, partial salvaging, and strict protection. At the altitude between $900 \mathrm{~m}$ to $1350 \mathrm{~m}$ above sea level, the dominant forest type is a mixture of beech, fir, and spruce on limestone covered mostly with brown soil types. The climate for the period 1975-2005 was assessed to be moderately continental with mean yearly precipitation of $991 \mathrm{~mm}$ and mean yearly temperature of $7.9{ }^{\circ} \mathrm{C}$ [28]. The study area has not experienced ungulate over-browsing, as has been the case in the mixed forests of some countries in South-East Europe $[35,36]$.

The first registered cutting activities in the Tara mountain date back to 1852. Mostly conifers with dbh above $40 \mathrm{~cm}$ were cut [37], while beech was spared until the mid 20th century [38]. Both conifers and beech were used to satisfy the needs of local wood processing mills for timber, with some being exported. Nevertheless, the landscape did not experience dramatic changes in tree species composition, since mostly single-tree harvesting was performed [24,39]. The first organized management plan was made in 1960. Since then, inventories in selection stand and an adjacent unmanaged stand (locally called Racanska Sljivovica) have been conducted every 10 years. The unmanaged stand was declared as a strict reserve in 1957, but regular measurements began simultaneously with the inventories of selection stand in 1960 .

A few years prior to national inventory, a smaller area (8.0 ha) that was only partly salvaged was first measured in 1955, although with somewhat less frequent measurements (see Data collection). This stand has been only partly salvaged in order to leave standing dead trees that were deemed not to jeopardize the stability and health of surrounding live trees. This means that single-tree mortality (e.g., due to competition or aging) has been partly tolerated; however, if a tree was broken by agents such as wind or snow, or if it was determined to suffer from beetle or fungi attack, it was felled and removed from the stand. This approach of low-intensity cutting was part of an experiment with the intention to increase the share of large trees and snags, but it differs from structural complexity enhancement approach described in the USA [4] as the latter had certain constraints. For instance, the rotated sigmoid diameter distribution was prescribed as one of the objectives, and target diameter was set to $90 \mathrm{~cm}$. In Tara, the initial objective in 1955 was to establish a negative exponential form with high basal area, no target diameter, and a certain amount of snags were allowed if they did not disturb a demographic equilibrium of live trees. Such an approach is not traditional in the region but was used in the study area solely as an experimental treatment.

On the other hand, no harvesting was performed in the unmanaged stand Tara, at least from 1957 to the present [40]. All of the mentioned stands are located in close proximity to each other and have been exposed to virtually the same climate and natural disturbance events, which enabled us to differentiate and examine the influence of the different types of forest management.

\subsection{Data Collection}

The stands in NP Tara were given special attention in the frame of the national forest inventory in Serbia where relatively large areas were fully callipered over time [41]. Since unmanaged stand and partly salvaged stand had similar site conditions (soil type, inclination, altitude, etc.), for proper 
comparison we also chose one stand from selection forest that had similar site conditions to those found in adjacent unmanaged stand and partly salvaged stand. The harvests in selection stand were conducted once every ten years, whereas target basal area was not set as a single value but as the range from $31 \mathrm{~m}^{2} \cdot \mathrm{ha}^{-1}$ to $38 \mathrm{~m}^{2} \cdot \mathrm{ha}^{-1}$. The area of selection stand that was studied amounted to $11.2 \mathrm{ha}$, whereas the area of the unmanaged stand was 15.4 ha. Both selection stand and unmanaged stand were fully callipered every ten years from 1960 to 2010. On the other hand, the measurements in partly salvaged stand started five years earlier and they were somewhat less frequent $(1955,1975$, and 2005). Nevertheless, we find them important for characterizing the long-term structural and compositional dynamics under partial salvage logging. The data for partly salvaged stand were collected on the total area of 8.0 ha where merely partial salvaging has been conducted.

At every inventory, the $\mathrm{dbh}$ of all stems $>10.0 \mathrm{~cm}$ were measured to the nearest $1.0 \mathrm{~mm}$. The stands were not sampled or replicated, but complete census of all trees was conducted in each of three studied stands. The total numbers of trees that were measured during every census are provided in the Appendix A, Table A1. For meaningful comparison of partly salvaged stand with selection stand and unmanaged stand in Tara, we used only the data from selection stand and unmanaged stand that were collected in the years 1960, 1980, and 2010, as those inventory years were closest to the measurement years in partly salvaged stand.

Standing dead trees with $\mathrm{dbh}>10.0 \mathrm{~cm}$ and height $>1.30 \mathrm{~m}$ were callipered from 1975 to 2005 in partly salvaged stand, whereas snags in unmanaged stand were inventoried only in 2010. Since repetitive measurements on snags were not available, the mortality rate could not be determined. Nevertheless, the one-time measurement in unmanaged stand provided useful information with respect to the long-term outcomes of strict protection, whereas the two measurements (in 1975 and 2005) gave us an insight into the density of snags in partly salvaged stand. Concerning selection stand in Tara, snags were not inventoried, since managers regularly remove damaged and dead trees from selection stands. Thus, their occurrence in selection stands in this part of Europe may be only temporary and accidental rather than the result of planned activities.

\subsection{Data Analysis}

A long-term experiment spanning 50 years was used to examine the effects of partial salvage logging, selection management, and strict protection on live-tree size distributions, species composition, and the abundance of standing dead trees in the study area. Diameter distributions were constructed using $10 \mathrm{~cm}$ diameter classes as applied by Silver et al. [19]. For detailed quantification that provides clear insight into the changes in dbh distribution shapes at the species- and stand level, we applied the method proposed by Janowiak et al. [42]. Mixed (linear, polynomial, cubic) regression models were calculated and best-fitting models were selected based on lowest Akaike information criterion (AIC) [43], whereas $\log _{10}$ of tree density +1 was regressed on all combinations of size class midpoints to the third exponent. Depending on the signs of coefficients, diameter distribution shapes could be classified into: Negative exponential $(-\mathrm{dbh})$; increasing- $q\left(-\mathrm{dbh}^{2}\right.$ or $\left.-\mathrm{dbh}^{3}\right)$; rotated sigmoid $(-\mathrm{dbh}+$ $\left.\mathrm{dbh}^{2}-\mathrm{dbh}^{3}\right)$; concave $\left(-\mathrm{dbh}+\mathrm{dbh}^{2},-\mathrm{dbh}+\mathrm{dbh}^{3}\right)$; or unimodal $\left(+\mathrm{dbh}-\mathrm{dbh}^{2},+\mathrm{dbh}-\mathrm{dbh}^{3}\right.$, $\left.+\mathrm{dbh}^{2}-\mathrm{dbh}^{3}\right)($ see $[42,44])$. If best model indicated variable shape $\left(-\mathrm{dbh}^{2}+\mathrm{dbh}^{3}\right.$ or $+\mathrm{dbh}-\mathrm{dbh}^{2}+$ $\left.\mathrm{dbh}^{3}\right)$, then the second best model was selected. The changes in live-tree size distribution shapes in selection stand, unmanaged stand, and partly salvaged stand were observed over the period of five decades, whereas partly salvaged stand was compared to selection stand and unmanaged stand in different time periods.

In order to test for differences in tree species composition among these stands, we applied a two-variable $\chi^{2}$-test, whereas species frequencies rather than their proportions or percentages were used. To avoid biased $\chi^{2}$ estimation for low expected frequencies (see [45]), we grouped the initial $10 \mathrm{~cm}$ classes into four size classes matching the following size categories: poles (dbh of $10.1 \mathrm{~cm}-20.0 \mathrm{~cm})$, small trees (dbh of $20.1 \mathrm{~cm}-30.0 \mathrm{~cm})$, medium trees $(\mathrm{dbh}$ of $30.1 \mathrm{~cm}-50.0 \mathrm{~cm})$, 
and large trees $(\mathrm{dbh}>50.0 \mathrm{~cm})$. A one-variable $\chi^{2}$-test was applied for comparison of snag density distributions in partly salvaged stand and unmanaged stand.

The intensity of basal area dynamics for large trees $>50 \mathrm{~cm}$ dbh was analyzed by using the large tree basal area index $\left(\mathrm{LTI}_{\mathrm{ba}}\right)$, which was adopted after Klopcic and Boncina [46], who employed a similar index for the total stand volume. In our study, the $\mathrm{LTI}_{\mathrm{ba}}$ represents a measure of the relative change in basal area of large trees $(>50 \mathrm{~cm} \mathrm{dbh})$, calculated as the quotient between this basal area at a particular point in time and the respective basal area of large trees at the first forest inventory. The index was computed for each tree species and also for total trees. The possible index values may range theoretically from -1 (all large trees removed from the stand before the final measurement) to $+\infty$.

\section{Results}

\subsection{Structural Characteristics of Live Trees}

In the first observation period (1955/1960), partly salvaged stand had the highest density, with 513 stems.ha ${ }^{-1}$, selection stand had 497 stems.ha ${ }^{-1}$, and unmanaged stand had the lowest density with 355 stems $\cdot \mathrm{ha}^{-1}$. A similar relationship was also observed two decades later (1975/1980). Nevertheless, by the end of the observation period (2005/2010), selection stand had the highest stem density, while the number of pole trees in partly salvaged stand decreased significantly, to the extent that it ended up with the lowest overall stem density (Figure 1).
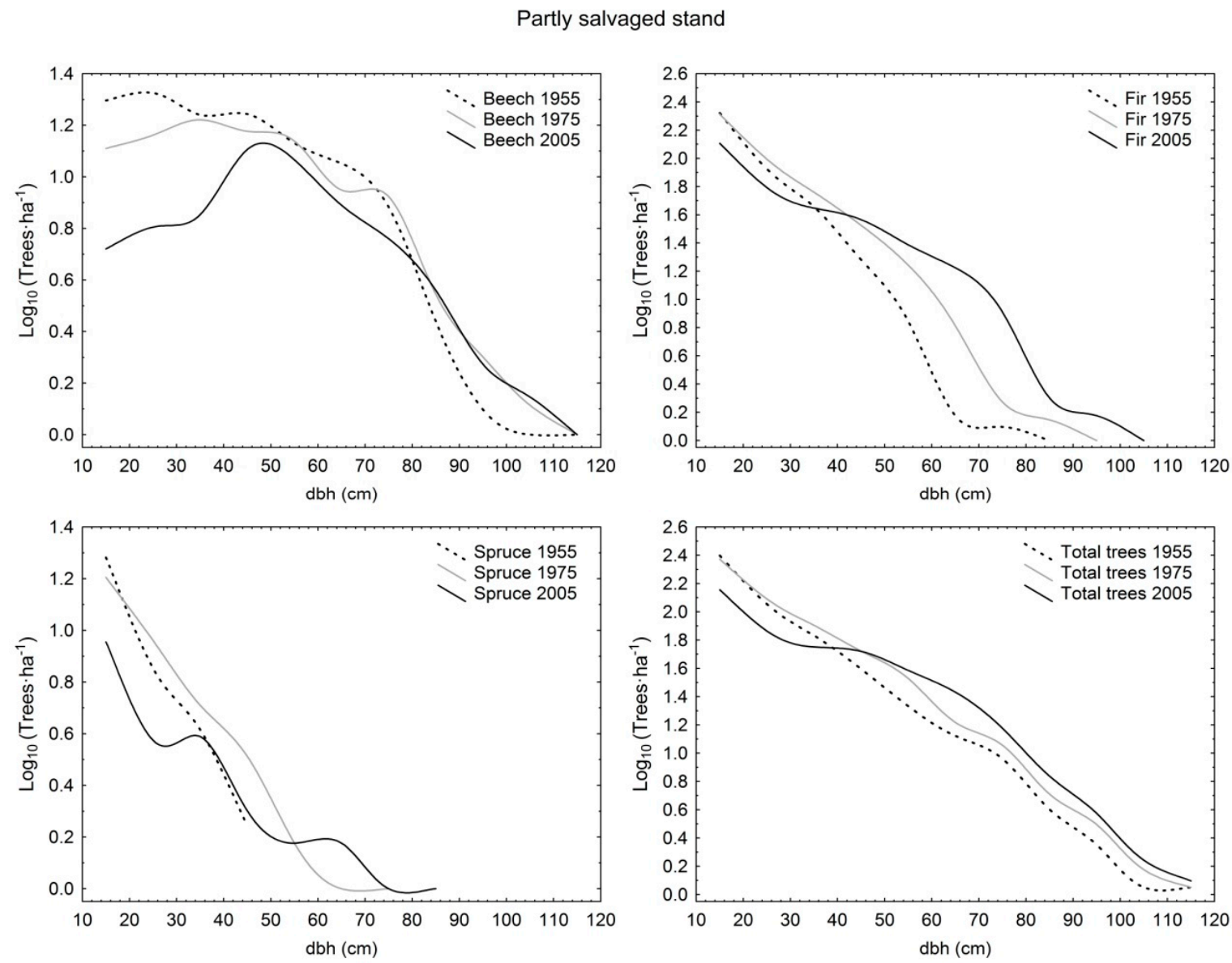

Figure 1. Diameter distributions of live trees with diameter at breast height $(\mathrm{dbh})>10 \mathrm{~cm}$ in partly salvaged stand in Tara Mountain in 1955, 1975, and 2005 per species and for total trees. 
Diameter distribution shapes were compared among partly salvaged stand, selection stand, and unmanaged stand in different time periods. At the beginning stage of observation (1955/1960), fir, spruce, and total trees in partly salvaged stand as well as total trees in selection stand had negative exponential distribution, whereas total trees in unmanaged stand exhibited an increasing- $q$ distribution. At this time, selection stand exhibited higher demographic stability compared to unmanaged stand as the dominant species of fir and spruce had rotated sigmoid shapes in the first, and increasing- $q$ and unimodal distributions in the latter, respectively. In the first period, only beech had the same distribution (increasing- $q$ ) in all three sites. In 1975/1980, fir in selection stand and unmanaged stand had the same shape (rotated sigmoid) as well as total trees in selection stand and partly salvaged stand (negative exponential), whereas the structural forms of all other comparative pairs differed by species and also total trees. Eventually, in the last observation period in 2005/2010, in selection stand all distributions by species and for total trees were rotated sigmoid, and in the unmanaged stand three out of four possible cases were also rotated sigmoid (only beech had the unimodal shape). On the other hand, partly salvaged stand exhibited more varied shapes, with fir having the rotated sigmoid shape, beech the unimodal shape, and spruce and total trees having the increasing- $q$ distribution form (Table 1; Figures 1-3).

\section{Selection stand}
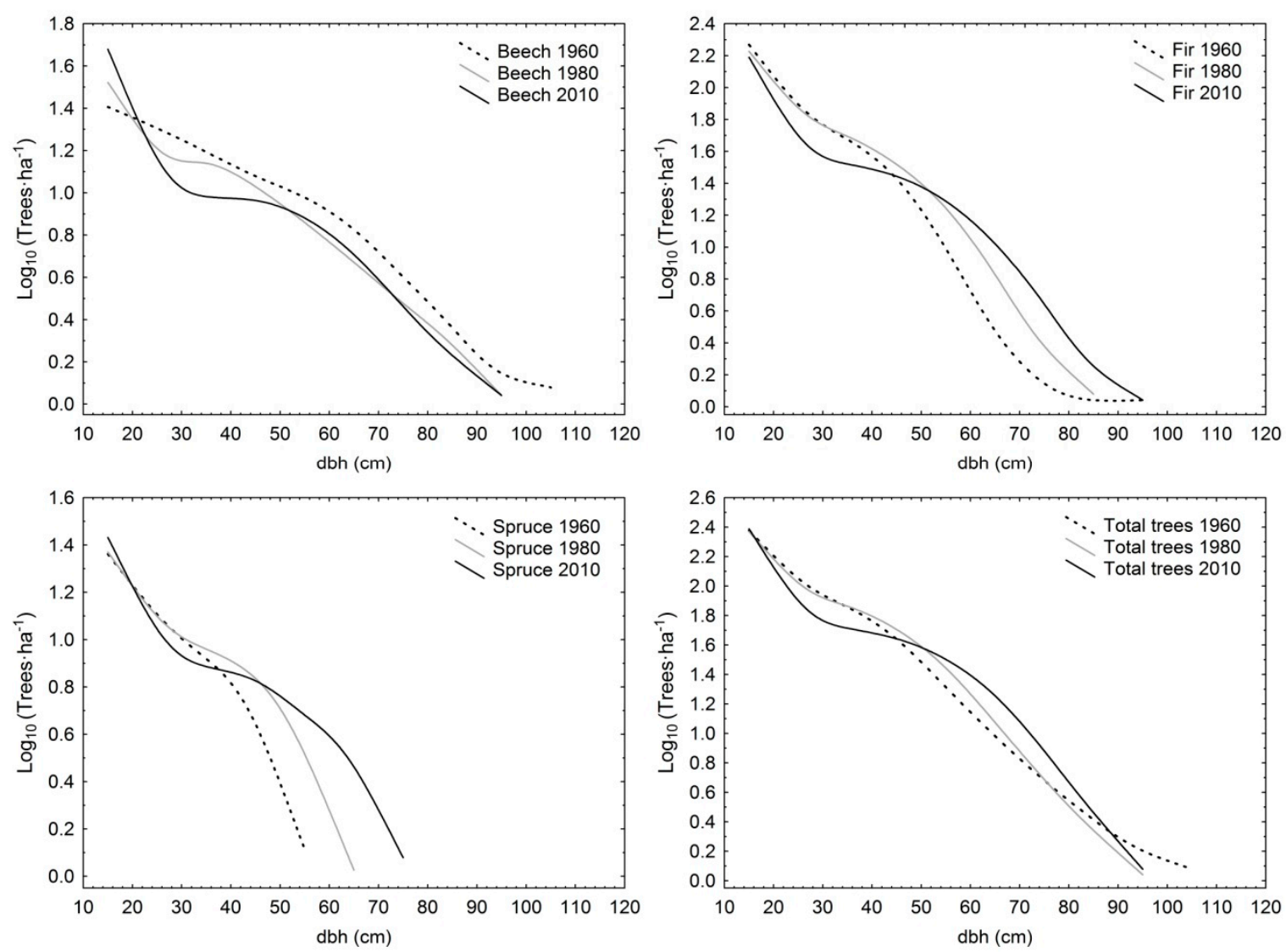

Figure 2. Diameter distributions of live trees with diameter at breast height $(\mathrm{dbh})>10 \mathrm{~cm}$ in selection-managed stand in Tara Mountain in 1960, 1980, and 2010 per species and for total trees. 
Table 1. The summary of best-fitting models and corresponding shapes of diameter distributions per species and total trees in differently managed stands across time in the study area.

\begin{tabular}{|c|c|c|c|c|c|c|c|c|c|c|c|c|}
\hline & \multicolumn{4}{|c|}{ Partly Salvaged Stand (1955) } & \multicolumn{4}{|c|}{ Selection Stand (1960) } & \multicolumn{4}{|c|}{ Unmanaged Stand (1960) } \\
\hline & Fir & Spruce & Beech & Total & Fir & Spruce & Beech & Total & Fir & Spruce & Beech & Total \\
\hline RMSE & 0.14 & 0.06 & 0.09 & 0.07 & 0.03 & 0.03 & 0.06 & 0.08 & 0.07 & 0.13 & 0.09 & 0.06 \\
\hline Adjusted $R^{2}$ & 0.97 & 0.98 & 0.96 & 0.99 & 0.98 & 0.99 & 0.99 & 0.94 & 0.99 & 0.91 & 0.95 & 0.98 \\
\hline$p$ & 0.0000 & 0.0054 & 0.0000 & 0.0000 & 0.0012 & 0.0032 & 0.0000 & 0.0015 & 0.0000 & 0.0015 & 0.0000 & 0.0000 \\
\hline AIC & -10.3 & -8.5 & -17.4 & -22.9 & -12.0 & -15.9 & -39.3 & -25.2 & -19.5 & -3.1 & -13.7 & -16.0 \\
\hline \multirow[t]{3}{*}{ Shape } & $\mathrm{NE}$ & NE & IQ & NE & RS & $\mathrm{NE}$ & IQ & $\mathrm{NE}$ & IQ & UNI & IQ & IQ \\
\hline & \multicolumn{4}{|c|}{ Partly Salvaged Stand (1975) } & \multicolumn{4}{|c|}{ Selection Stand (1980) } & \multicolumn{4}{|c|}{ Unmanaged Stand (1980) } \\
\hline & Fir & Spruce & Beech & Total & Fir & Spruce & Beech & Total & Fir & Spruce & Beech & Total \\
\hline RMSE & 0.08 & 0.07 & 0.05 & 0.05 & 0.06 & 0.03 & 0.06 & 0.07 & 0.06 & 0.24 & 0.13 & 0.05 \\
\hline Adjusted $R^{2}$ & 0.99 & 0.98 & 0.98 & 0.99 & 0.98 & 0.99 & 0.98 & 0.93 & 0.98 & 0.80 & 0.86 & 0.98 \\
\hline$p$ & 0.0000 & 0.0000 & 0.0004 & 0.0000 & 0.0001 & 0.0001 & 0.0000 & 0.0018 & 0.0001 & 0.023 & 0.0004 & 0.0001 \\
\hline AIC & -19.0 & -13.7 & -27.7 & -29.2 & -11.3 & -16.1 & -23.9 & -18.4 & -14.5 & 3.8 & -6.2 & -9.5 \\
\hline \multirow[t]{3}{*}{ Shape } & $\mathrm{NE}$ & $\mathrm{NE}$ & UNI & $\mathrm{NE}$ & RS & RS & $\mathrm{NE}$ & $\mathrm{NE}$ & RS & IQ & IQ & RS \\
\hline & \multicolumn{4}{|c|}{ Partly Salvaged Stand (2005) } & \multicolumn{4}{|c|}{ Selection Stand (2010) } & \multicolumn{4}{|c|}{ Unmanaged Stand (2010) } \\
\hline & Fir & Spruce & Beech & Total & Fir & Spruce & Beech & Total & Fir & Spruce & Beech & Total \\
\hline RMSE & 0.11 & 0.08 & 0.07 & 0.09 & 0.03 & 0.06 & 0.09 & 0.09 & 0.10 & 0.07 & 0.06 & 0.06 \\
\hline Adjusted $R^{2}$ & 0.98 & 0.94 & 0.95 & 0.98 & 0.99 & 0.99 & 0.97 & 0.98 & 0.95 & 0.97 & 0.95 & 0.99 \\
\hline$p$ & 0.0000 & 0.0004 & 0.0000 & 0.0000 & 0.0001 & 0.0001 & 0.0005 & 0.0001 & 0.0017 & 0.0001 & 0.0000 & 0.0000 \\
\hline AIC & -13.8 & -11.5 & -21.6 & -18.3 & -8.4 & -19.5 & -11.3 & -12.2 & -13.3 & -16.7 & -21.8 & -21.1 \\
\hline Shape & RS & IQ & UNI & IQ & RS & RS & RS & RS & RS & RS & UNI & RS \\
\hline
\end{tabular}

RMSE—root mean square error; AIC—Akaike information criterion; Structural shapes: UNI—convex or unimodal shape, RS—rotated sigmoid, IQ—increasing- $q$, NE—negative exponential, (sensu Janowiak et al. [42]). 
From the perspective of temporal changes, the rotated sigmoid distribution showed stability at the species level for 50 years in selection stand (fir) and for 30 years in selection stand (spruce) and unmanaged stand (fir). The negative exponential and increasing- $q$ shapes were less stable, as they were maintained for only two decades. The negative exponential shape, after initially being determined for fir and spruce in partly salvaged stand, eventually transformed into the rotated sigmoid (fir) and increasing- $q$ (spruce) shapes. A similar demographic trajectory was determined for total trees in selection stand. Only beech in partly salvaged stand and unmanaged stand showed a different structural trajectory by switching from the initial increasing- $q$ form into an unimodal distribution (Table 1; Figures 1-3).
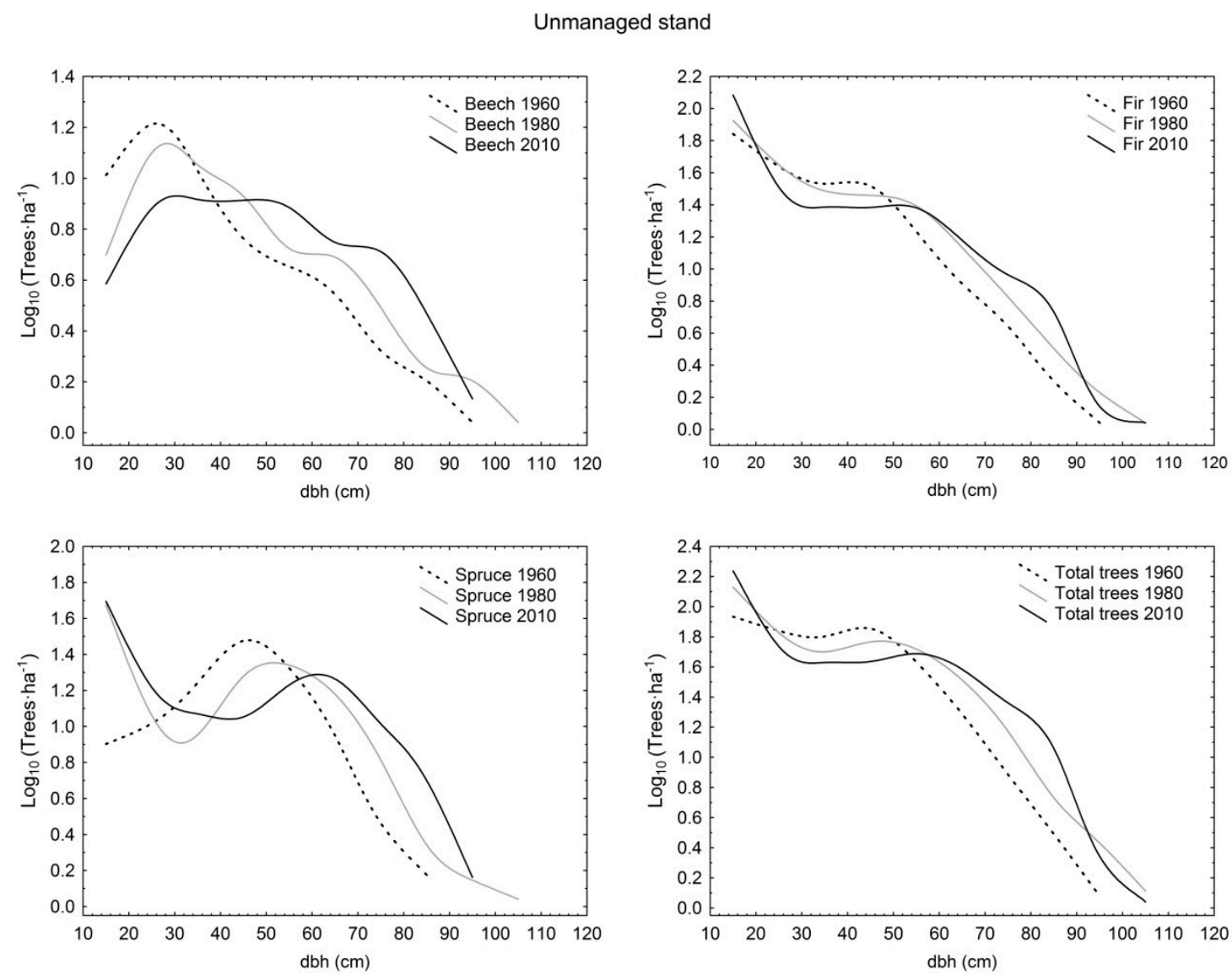

Figure 3. Diameter distributions of live trees with diameter at breast height $(\mathrm{dbh})>10 \mathrm{~cm}$ in unmanaged stand in Tara Mountain in 1960, 1980, and 2010 per species and for total trees.

\subsection{Tree Species Composition}

At the beginning of observation (1955/1960), significant differences in tree species composition were determined among partly salvaged stand, selection stand, and unmanaged stand. Despite different cutting strategies, however, no significant difference was found five decades later between selection stand and partly salvaged stand, whereas these two stands differed significantly from adjacent unmanaged stand throughout whole study period $\left(\chi^{2}\right.$-tests, $\left.p<0.05\right)$. Partly salvaged stand exhibited the largest decrease in overall stem density over time (Appendix A, Table A2). Although we were not able to investigate spatial interactions among tree species based on the available dataset, it is important to point out that the share of beech was higher in partly salvaged stand compared to selection stand and unmanaged stand throughout the whole study period (Table 2; Figure 4). In the final observation year, the share of large beech trees ( $>50 \mathrm{~cm} \mathrm{dbh}$ ) amounted to $40 \%$ of the total basal area of large trees in partly salvaged stand, whereas in selection stand and unmanaged stand the share of such 
beech trees amounted to only $25 \%$ and $16 \%$, respectively (Appendix A, Tables A3 and A4). With respect to total basal area, it remained highest in unmanaged stand throughout the whole period of five decades $\left(42.4 \mathrm{~m}^{2} \cdot \mathrm{ha}^{-1}-56.7 \mathrm{~m}^{2} \cdot \mathrm{ha}^{-1}\right)$, moderate in partly salvaged stand $\left(38.1 \mathrm{~m}^{2} \cdot \mathrm{ha}^{-1}-49.9 \mathrm{~m}^{2} \cdot \mathrm{ha}^{-1}\right)$, and smallest in selection stand $\left(34.0 \mathrm{~m}^{2} \cdot \mathrm{ha}^{-1}-37.0 \mathrm{~m}^{2} \cdot \mathrm{ha}^{-1}\right)$ (Figure 4$)$.

Table 2. Long-term changes in tree species composition (\%) of stands in Tara Mountain under different management regimes such as (i) partial salvaging, (ii) selection system, and (iii) strict protection in unmanaged stand.

\begin{tabular}{ccccccc}
\hline & \multicolumn{5}{c}{ Stem Density Per Hectare (\%) } \\
\hline Stand Category & Year & Beech (\%) & Fir (\%) & Spruce (\%) & Maple (\%) & Other sp. (\%) \\
\hline \multirow{3}{*}{ Partly Salvaged Stand } & 1955 & 21.9 & 71.5 & 6.3 & 0.3 & 0.0 \\
& 1975 & 17.4 & 76.0 & 6.4 & 0.2 & 0.0 \\
& 2005 & 15.3 & 78.6 & 5.4 & 0.7 & 0.0 \\
\hline \multirow{3}{*}{ Selection Stand } & 1960 & 17.8 & 69.5 & 10.1 & 1.5 & 1.1 \\
& 1980 & 16.5 & 68.8 & 11.3 & 1.7 & 1.7 \\
& 2010 & 19.2 & 62.2 & 13.1 & 3.6 & 1.9 \\
\hline \multirow{3}{*}{ Unmanaged Stand } & 1960 & 13.2 & 57.3 & 25.9 & 0.2 & 3.4 \\
& 1980 & 11.0 & 56.0 & 30.5 & 0.2 & 2.3 \\
& 2010 & 9.7 & 58.1 & 30.9 & 0.2 & 1.1 \\
\hline
\end{tabular}
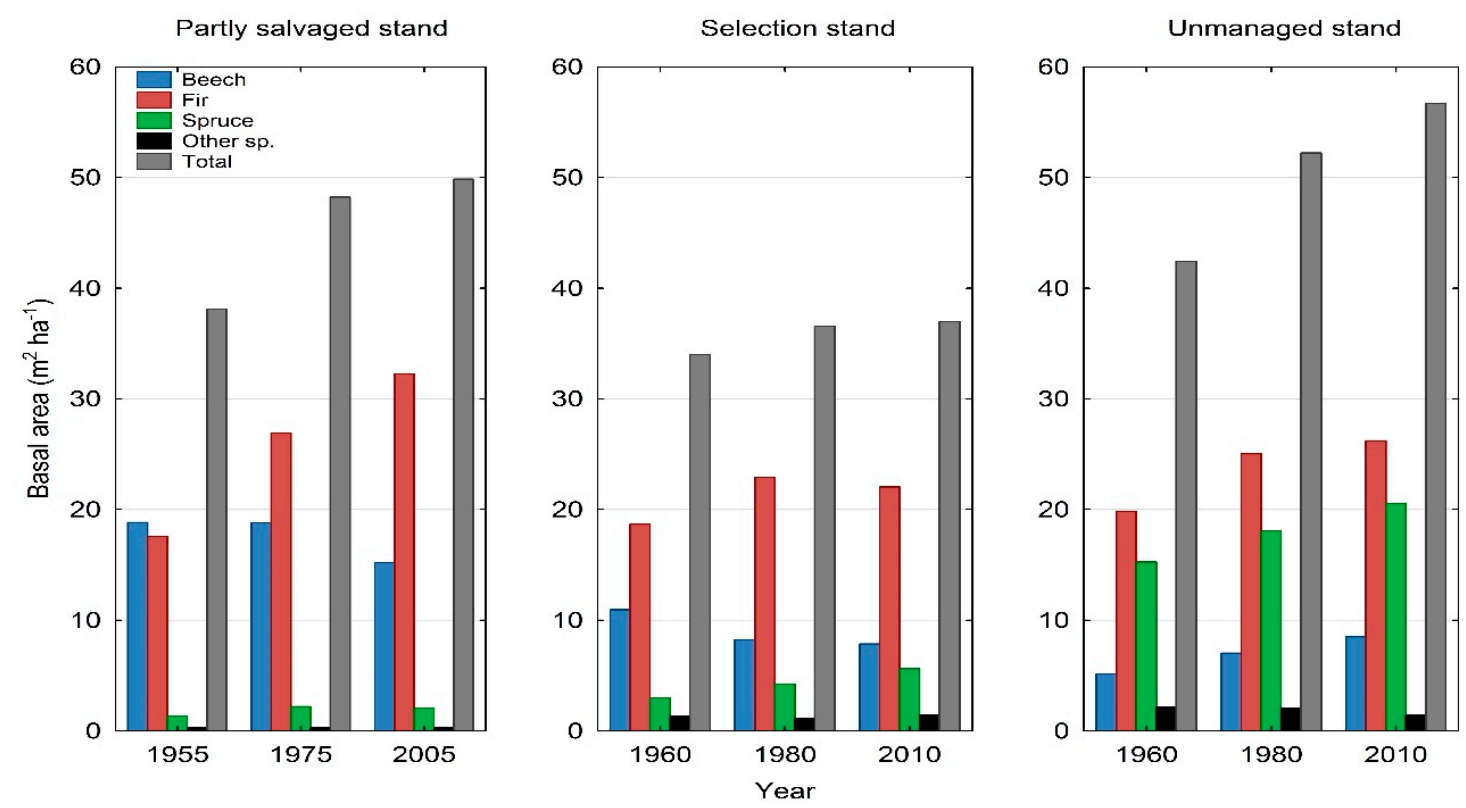

Figure 4. Species-specific and total basal area changes across time in partially salvaged stand, selection-managed stand, and unmanaged stand in the study area.

Whereas in partly salvaged stand all species experienced a decrease in the density of pole trees by $43 \%$, their recruitment in selection stand and unmanaged stand simultaneously increased by $2 \%$ and $102 \%$, respectively. In selection stand, only fir experienced a relatively small decrease in pole trees $(17 \%)$, while in unmanaged stand, beech poles almost disappeared from 1960 to 2010. On the other hand, the density of fir poles in this unmanaged stand increased in the same period by $74 \%$. Regarding the density of large trees $>50 \mathrm{~cm}$ dbh, their relative recruitment over five decades was highest in partly salvaged stand $(91 \%)$, while unmanaged stand and selection stand followed with $72 \%$ and $68 \%$, respectively. In all studied stands, conifers had higher recruitment rates than beech (for details see Appendix A). The increase in the 
share of large beech trees in unmanaged stand was relatively high; however, the absolute share of beech in the species composition of this stand remained low (Table 2; Figure 4).

The share of sycamore maple (Acer pseudoplatanus L.), a more light-demanding species than fir, beech, and spruce, increased in selection stand from $1.5 \%$ to $3.6 \%$ and in partly salvaged stand from $0.3 \%$ to $0.7 \%$. In unmanaged stand, the share of maple was lowest, amounting to only $0.2 \%$ of the total stem density throughout the whole study period (Table 2).

In contrast to the species shares based on stem density, the composition based on basal area showed a much higher share of conifers in unmanaged stand compared to partly salvaged stand and selection stand (Figure 4). The dynamics of basal area of large trees expressed with the $\mathrm{LTI}_{\mathrm{ba}}$ index showed similar recruitment of this parameter between partly salvaged stand and unmanaged stand (0.94 and 0.98 , respectively), whereas the index value for basal area of large trees in selection stand amounted to 0.60 . However, on the species level, large fir trees in partly salvaged stand exhibited the highest value $\left(\mathrm{LTI}_{\mathrm{ba}}=6.12\right)$ due to an absolute basal area increase from $2.4 \mathrm{~m}^{2} \cdot \mathrm{ha}^{-1}$ to $16.8 \mathrm{~m}^{2} \cdot \mathrm{ha}^{-1}$ over the 50-year period (Figure 4). All $\mathrm{LTI}_{\mathrm{ba}}$ values are provided in the Appendix A, Table A5.

\subsection{Standing Dead Trees}

With respect to standing dead trees in partly salvaged stand, there were a total of 12 snags.ha $^{-1}$ in 1975 and 18 snags.ha ${ }^{-1}$ in 2005. Between the two periods, the number of snags with diameters between $20-40 \mathrm{~cm}$ increased most noticeably (Figure 5), which probably caused the two distributions to differ significantly $\left(\chi^{2}=22.1, p=0.0047\right)$. Despite this increase in snag density in partly salvaged stand over time, there was a significant difference in snag diameter distributions between this stand and adjacent unmanaged stand in the final period 2005/2010 $\left(\chi^{2}=38.07, p=0.0003\right)$. Unmanaged stand was characterized by a total of 68 snags $\cdot \mathrm{ha}^{-1}$, of which large snags with $\mathrm{dbh}>50 \mathrm{~cm}$ amounted to 16 snags $\cdot$ ha $^{-1}$. On the other hand, partly salvaged stand had on average 2 large snags $\cdot$ ha $^{-1}$ (Figure 5). The basal area of snags in partly salvaged stand increased between the two periods from $0.9 \mathrm{~m}^{2} \cdot \mathrm{ha}^{-1}$ to $1.4 \mathrm{~m}^{2} \cdot \mathrm{ha}^{-1}$, whereas the basal area of snags in unmanaged stand was noticeably higher, amounting to $7.9 \mathrm{~m}^{2} \cdot \mathrm{ha}^{-1}$.
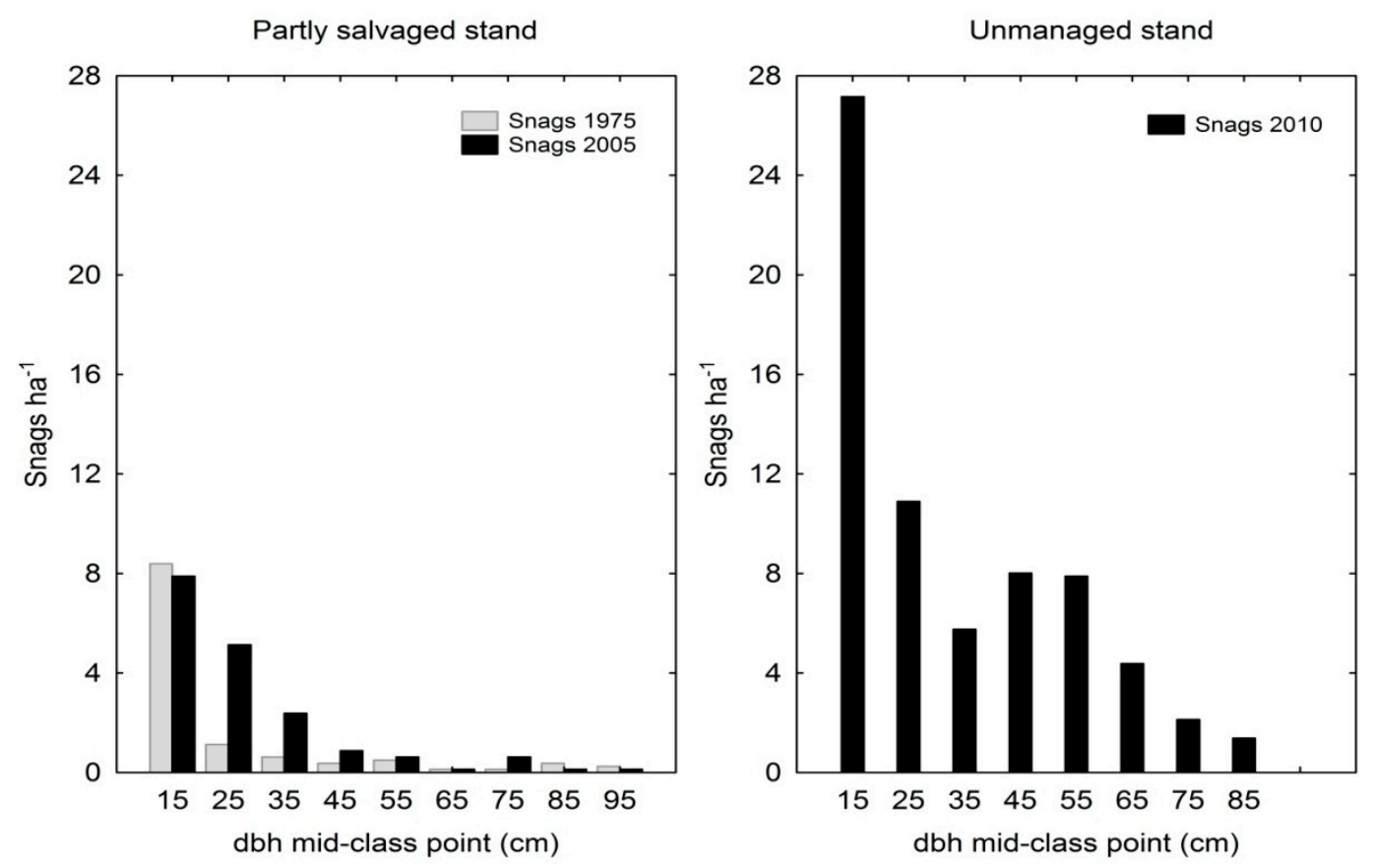

Figure 5. Snags in partly salvaged stand and unmanaged stand in the study area. 


\section{Discussion}

\subsection{Structure of Living Trees}

The enhancement of old-growth attributes over large forested landscapes is currently the subject of debate. While there are many arguments for strict protection (e.g., [17,47]), a number of active silvicultural techniques have been recently suggested to accelerate large tree recruitment $[4,48]$ or to naturally regenerate and preserve certain tree species $[49,50]$. Our study contributes to previous research by showing that partial salvage logging could also serve as a useful technique for restoring old-growth attributes such as large-sized trees and snags while maintaining tree-size demographic equilibrium. Under partial salvage logging, the negative exponential diameter distribution was maintained for two decades (1955-1975) before eventually being transformed into the increasing- $q$ form in 2005. While this form occasionally led to unimodal structure, e.g., beech, in unmanaged stand and partly salvaged stand, it more often transformed into more sustainable rotated sigmoid or negative exponential shapes, as shown in the examples from selection stand and unmanaged stand.

Although our dataset did not allow us to investigate small-scale spatial interactions among tree species, other studies from beech-conifer forests have reported that the recruitment of young trees decreases when the share of beech increases in total basal area or total growing stock [25,51,52]. Given that the share of beech was highest in partly salvaged stand, this may explain why partial salvaging failed to maintain the negative exponential distribution or establish the rotated sigmoid distribution, whereas the cumulative dbh structure of adjacent unmanaged stand, even under strict protection, changed from the increasing- $q$ into the rotated sigmoid form. It is also important to note that very high total basal area in unmanaged stand did not impede the maintenance of the rotated sigmoid structure. Similar outcomes were reported for the old-growth forest Janj in Bosnia-Herzegovina [25]. Thus, partial salvaging combined with removal of some large beech trees could result in more large fir and spruce trees making up a greater share of total basal area, which would create conditions for establishing the rotated sigmoid structure. Such an approach might be a sound solution when managing for old-growth conditions [4,7], at least in mixed beech-fir-spruce stands.

Negative exponential dbh distribution usually transforms into rotated sigmoid shape in selection forests as a result of the increase in basal area of large trees (see [53]). This was exactly what happened in selection stand in Tara mountain, primarily due to the increase in basal area of conifers by 2010 . Although initially the negative exponential form was one of the management goals in selection stand [28], the outcome of applied selection system was not a targeted negative exponential form but actually the rotated sigmoid form. This result corroborates the statements by Schütz [54] that negative exponential form is difficult to establish and maintain. In addition, the rotated sigmoid shape proved to be sustainable for a longer period than the negative exponential form. Therefore, the rotated sigmoid distribution may be considered as a sound alternative to the negative exponential structure in the context of selection management. Schütz [54] indicated that the rotated sigmoid shape occurred in Swiss selection forests because medium-sized trees experienced accelerated diameter growth. In selection stand in Tara, however, this form occurred as a consequence of a slight decrease in medium-sized trees (probably due to cutting) and simultaneous increase in the recruitment of large-sized trees $>50 \mathrm{~cm}$ in dbh. Thus, tree-size demographic equilibrium was not put at risk, as the rotated sigmoid form proved to be sustainable over five decades (in the case of fir in selection stand). Our results hence confirm the findings from northern hardwoods that demonstrated similar elasticity in the rotated sigmoid structure [42,55].

Although the negative exponential form may have certain limitations, it may be applicable when restoring some old-growth attributes if the target diameter is increased in mixed beech-fir-spruce forests. This is at least one of the conclusions from recent research in the old-growth forest Lom that is also located in the Dinaric Mountains (see [56]). On the other hand, the present study indicated that besides the rotated sigmoid and negative exponential structural forms, alternative options for management towards higher degree of old-growthness could also be pursued in the increasing- $q$ 
form, which eventually occurred in partly salvaged stand. Similar outcomes were obtained by Gronewold et al. [16] in the northern hardwoods of Michigan (USA). Moreover, the same authors reported that the increasing- $q$ structure may be sustained over time under single-tree selection. Several other studies have also determined the increasing- $q$ shape in managed and unmanaged northern hardwoods, although it was less frequently reported than rotated sigmoid and negative exponential distributions $[4,42,55,57]$.

In our study, the increasing- $q$ shape was sustained for a maximum of two decades, which in certain circumstances may be considered as a drawback. Nevertheless, switching between rotated sigmoid, negative exponential, and increasing- $q$ shapes depends on tree species composition, and the structural form may be changed in a short period of time (two to three decades) even by the application of only partial salvaging. Therefore, any of these distribution forms may be acceptable when managing towards old-growth conditions, at least in mixed beech-fir-spruce forests.

Some authors have already proposed the modification of conventional selection systems to promote old-growth attributes for northern hardwoods (e.g., [4,16]). We believe such modifications might be also possible in beech-fir-spruce stands in South-East Europe. Namely, our results showed a decrease in stem density and an increase in basal area in selection stand without disruption of demographic equilibrium over a period of five decades. Similar results were reported by O'Hara et al. [58] for Swiss plenter forests composed of the same tree species. This confirms the statement that high wood productivity is rather stable in selection stands, even when tree density is reduced [59]. Consequently, modifying selection systems towards a higher degree of old-growthness might be feasible in practice. Please note, however, that our case study did not include the replication of stands, and additional studies are necessary to extrapolate the outcomes to the broader scale. Thus, the question of the acceptance of alternative silvicultural techniques on a wider scale goes beyond the scope of our study and remains a challenge for future research and forest management.

\subsection{The Influence of Management Regimes on Tree Species Composition}

The study showed that different management regimes may create similar structural forms, but that the effects on tree species composition were varied. From a statistical viewpoint, both selection stand and partly salvaged stand had significantly different tree species compositions than adjacent unmanaged stand. Similar outcomes were reported when comparing old-growth forests and managed forests in Bosnia-Herzegovina [25]. This indicates that, despite climatic changes, management practices still have a large influence on the structural and compositional dynamics of mixed beech-fir-spruce stands.

With respect to tree species replacement patterns, a number of studies [12,60-63] have reported long-term fir/spruce decline and beech progression in European old-growth forests, which have sometimes been ascribed to the effects of climate change. Likewise, in managed forests across Europe, where beech was practically eliminated in 19th and 20th century, we now face a boomerang effect as beech naturally fights to reoccupy its areas. The present study revealed, however, that forest management still has a crucial impact on tree species replacement patterns, at least with respect to mixed beech-fir-spruce stands. The results also showed that in partly salvaged stand and unmanaged stand in Tara, beech is in decline and silver fir dominates all stand layers. However, this result should be treated with caution as we do not have the detailed information on possible human activities in the unmanaged stand prior to official strict protection in 1957. It is yet important to note that Petritan et al. [52] also reported successful recruitment of silver fir in old-growth forest Sinca in Romania, so further studies are needed to check if these are the isolated cases.

Given that every silvicultural approach shortens the lifespan of trees, our results support the conclusions of Vrška et al. [64] on the importance of cyclic replacement among tree species. Although fir and spruce are sensitive species in Serbia because they are close to the southern edge of their natural range, it seems that beech-fir-spruce stands are still rather stable compositionally (see also [56]). This finding may be important for the future management of these mixed forests; however, long-term research is needed to clarify the influence of climate change on each constituent species (see [65]). 


\subsection{Standing Dead Trees in Partly Salvaged Stand and Unmanaged Stand in Tara}

Total snag density in unmanaged stand Tara was higher compared to other Dinaric old-growth forests as well as old-growth forests in northern hardwoods [55], but a common characteristic of all Dinaric old-growth forests is the similar density of large snags $>50 \mathrm{~cm}$ dbh $\left(16 \mathrm{ha}^{-1}-19 \mathrm{ha}^{-1}\right)$ (e.g., $[66,67])$. In certain situations, the discrepancy in snag densities between forests managed with conventional silvicultural systems and unmanaged references might not be evident [16]. Nonetheless, significant differences between managed and unmanaged forests are typically reported [68]. Although we observed the effects of an unconventional partial salvaging approach, the stem density and basal area of snags in partly salvaged stand were also significantly lower compared to the unmanaged stand.

Despite this, partial salvage logging led to a noticeable increase in snag density between 1975 and 2005. The largest increase in snags occurred in the $20 \mathrm{~cm}-40 \mathrm{~cm}$ dbh range, but large snags are also of special interest as they contain a number of microhabitats [7]. So far, however, few studies have proposed threshold values for large snag density in managed European stands. While some authors have suggested five snags with $\mathrm{dbh}>30 \mathrm{~cm}$ per hectare (e.g., [69]), others have proposed up to nine snags with $\mathrm{dbh}>43 \mathrm{~cm}$ per hectare [68]. However, the conventional selection systems that are usually applied in montane beech-conifer stands usually do not achieve these values $[66,68]$. In our case, even partly salvaged stand has heretofore failed to meet the levels proposed above. Nevertheless, considering the significant recruitment of live veteran trees in the last few decades under partial salvaging, there is obviously great potential to increase the density of large snags in partly salvaged stand in the near future.

\section{Conclusions}

Different management regimes resulted in significant differences in tree species composition between studied managed and unmanaged stands over a period of five decades. Contrary to a number of recent studies that reported the issues with the recruitment of young fir trees in European old-growth forests, in the unmanaged stand in Tara there was actually a problem with beech recruitment. However, this result should be treated with caution, as there is no information on possible human activities before strict protection in 1957. If such activities took place, they certainly influenced cyclic replacement trajectory among tree species (see [64]). Similar outcomes regarding fir and beech recruitment were determined for selection stand in Tara, however, the influence of forestry in this managed stand clearly showed that silvicultural practices still have major influence on tree species composition despite climate change.

On the other hand, despite the greater share of large-size trees in unmanaged stand, the diameter distributions of studied managed and unmanaged stands had the same structural forms in certain time periods. Since increasing- $q$ and negative exponential forms most often transformed into rotated sigmoid form over time and with increase of basal area, the application of rotated sigmoid structure seems to be most practical if the management goal is to increase the share of large living trees.

Considering very low share of old-growth forests in Europe and worldwide, the promotion of old-growth attributes should be pursued. To this end, significant progress could be made if partial salvaging (instead of total salvaging) were to be included in conventional selection systems, at least on designated land units. Contrary to total salvaging, the study showed that partial salvaging may serve as a good alternative to promoting old-growth attributes such as large veteran trees and a small but valuable share of large snags. Forest managers could partly tolerate very large snags as their limited presence did not endanger demographic equilibrium of living trees in studied beech-fir spruce stands. Nonetheless, additional studies are necessary to investigate the full range of effects of partial salvage logging.

Author Contributions: Data curation, all authors; Formal analysis, S.K.; Investigation, S.K., M.M. and S.O.; Methodology, S.K.; Project administration, M.M.; Writing-original draft, S.K.; Writing-review \& editing, all authors. 
Funding: The research was funded by the Ministry of Education, Science and Technological Development (Serbia) in the frame of the project "Sustainable management of the total forest potentials in the Republic of Serbia"-EVBR 37008. We are also grateful to the Ministry of Science and Higher Education (MNiSW, Poland) for supporting open access publishing and the English proofreading of the article in the frame of Statutory funds: DS-3418/ZBiPL/2018.

Acknowledgments: For continuing cooperation, the authors would like to express special thanks to the administration of the National Park Tara.

Conflicts of Interest: The authors declare no conflict of interest.

\section{Appendix A}

Table A1. Total numbers of trees for which diameters at breast height ( $\mathrm{dbh}, 1.30 \mathrm{~m}$ above ground) were measured during every inventory (complete census) in partly salvaged stand (area 8.0), selection-managed stand (area $11.2 \mathrm{ha}$ ), and unmanaged stand (area $15.4 \mathrm{ha}$ ).

\begin{tabular}{cccc}
\hline & \multicolumn{3}{c}{ Partly Salvaged Stand } \\
\hline Inventory year & 1955 & 1975 & 2005 \\
Total number of measured trees & 4104 & 4440 & 3296 \\
\hline & \multicolumn{4}{c}{ Selection Stand } \\
\hline Inventory year & 1960 & 1980 & 2010 \\
Total number of measured trees & 5567 & 5622 & 5298 \\
\hline & \multicolumn{3}{c}{ Unmanaged Stand } \\
\hline Inventory year & 1960 & 1980 & 2010 \\
Total number of measured trees & 5467 & 6314 & 6591 \\
\hline
\end{tabular}

Table A2. Stem density and basal area (BA) for different size categories in partly salvaged-logged stand in Tara Mountain across five decades.

\begin{tabular}{|c|c|c|c|c|c|c|}
\hline \multicolumn{7}{|c|}{ Partly Salvaged Stand } \\
\hline & \multicolumn{2}{|c|}{ Beech 1955} & \multicolumn{2}{|c|}{ Beech 1975} & \multicolumn{2}{|c|}{ Beech 2005} \\
\hline Size category & stems ha ${ }^{-1}$ & BA $\left(\mathrm{m}^{2} \mathrm{ha}^{-1}\right)$ & stems ha ${ }^{-1}$ & BA $\left(\mathrm{m}^{2} h \mathrm{~h}^{-1}\right)$ & stems ha ${ }^{-1}$ & $\mathrm{BA}\left(\mathrm{m}^{2} \mathrm{ha}^{-1}\right)$ \\
\hline pole trees & 20 & 0.35 & 13 & 0.23 & 5 & 0.09 \\
\hline small trees & 21 & 1.04 & 15 & 0.71 & 6 & 0.31 \\
\hline medium trees & 35 & 4.46 & 32 & 3.99 & 20 & 2.72 \\
\hline large trees & 37 & 13.00 & 37 & 13.89 & 32 & 12.07 \\
\hline \multirow[t]{2}{*}{$\Sigma$} & 113 & 18.85 & 96 & 18.82 & 63 & 15.19 \\
\hline & \multicolumn{2}{|c|}{ Fir 1955} & \multicolumn{2}{|c|}{ Fir 1975} & \multicolumn{2}{|c|}{ Fir 2005} \\
\hline Size category & stems ha ${ }^{-1}$ & $\mathrm{BA}\left(\mathrm{m}^{2} \mathrm{ha}^{-1}\right)$ & stems ha ${ }^{-1}$ & $\mathrm{BA}\left(\mathrm{m}^{2} \mathrm{ha}^{-1}\right)$ & stems ha ${ }^{-1}$ & $\mathrm{BA}\left(\mathrm{m}^{2} \mathrm{ha}^{-1}\right)$ \\
\hline pole trees & 210 & 3.70 & 205 & 3.63 & 128 & 2.26 \\
\hline small trees & 84 & 4.13 & 99 & 4.84 & 62 & 3.05 \\
\hline medium trees & 65 & 7.41 & 91 & 10.87 & 81 & 10.12 \\
\hline large trees & 9 & 2.36 & 27 & 7.59 & 52 & 16.81 \\
\hline \multirow[t]{2}{*}{$\Sigma$} & 367 & 17.60 & 422 & 26.93 & 323 & 32.24 \\
\hline & \multicolumn{2}{|c|}{ Spruce 1955} & \multicolumn{2}{|c|}{ Spruce 1975} & \multicolumn{2}{|c|}{ Spruce 2005} \\
\hline Size category & stems ha ${ }^{-1}$ & BA $\left(\mathrm{m}^{2} \mathrm{ha}^{-1}\right)$ & stems ha ${ }^{-1}$ & BA $\left(\mathrm{m}^{2} \mathrm{ha}^{-1}\right)$ & stems ha ${ }^{-1}$ & $\mathrm{BA}\left(\mathrm{m}^{2} \mathrm{ha}^{-1}\right)$ \\
\hline pole trees & 19 & 0.34 & 16 & 0.28 & 9 & 0.16 \\
\hline small trees & 7 & 0.35 & 9 & 0.45 & 4 & 0.18 \\
\hline medium trees & 6 & 0.68 & 8 & 1.01 & 6 & 0.69 \\
\hline large trees & 0 & 0.00 & 2 & 0.45 & 3 & 1.05 \\
\hline \multirow[t]{2}{*}{$\Sigma$} & 32 & 1.36 & 35 & 2.20 & 22 & 2.09 \\
\hline & \multicolumn{2}{|c|}{ Total trees 1955} & \multicolumn{2}{|c|}{ Total trees 1975} & \multicolumn{2}{|c|}{ Total trees 2005} \\
\hline Size category & stems ha ${ }^{-1}$ & $\mathrm{BA}\left(\mathrm{m}^{2} \mathrm{ha}^{-1}\right)$ & stems ha ${ }^{-1}$ & $\mathrm{BA}\left(\mathrm{m}^{2} \mathrm{ha}^{-1}\right)$ & stems ha ${ }^{-1}$ & $\mathrm{BA}\left(\mathrm{m}^{2} \mathrm{ha}^{-1}\right)$ \\
\hline pole trees & 249 & 4.39 & 234 & 4.14 & 143 & 2.53 \\
\hline small trees & 113 & 5.52 & 123 & 6.02 & 73 & 3.57 \\
\hline medium trees & 106 & 12.62 & 131 & 15.91 & 107 & 13.58 \\
\hline large trees & 46 & 15.56 & 66 & 22.17 & 88 & 30.18 \\
\hline$\Sigma$ & 513 & 38.09 & 555 & 48.23 & 412 & 49.86 \\
\hline
\end{tabular}


Table A3. Stem density and basal area (BA) for different size categories in selection managed stand in Tara Mountain across five decades.

\begin{tabular}{|c|c|c|c|c|c|c|}
\hline \multicolumn{7}{|c|}{ Selection Stand } \\
\hline & \multicolumn{2}{|c|}{ Beech 1960} & \multicolumn{2}{|c|}{ Beech 1980} & \multicolumn{2}{|c|}{ Beech 2010} \\
\hline Size category & stems ha ${ }^{-1}$ & $\mathrm{BA}\left(\mathrm{m}^{2} \mathrm{ha}^{-1}\right)$ & stems ha ${ }^{-1}$ & $\mathrm{BA}\left(\mathrm{m}^{2} \mathrm{ha}^{-1}\right)$ & stems ha ${ }^{-1}$ & $\mathrm{BA}\left(\mathrm{m}^{2} \mathrm{ha}^{-1}\right)$ \\
\hline pole trees & 25 & 0.43 & 32 & 0.57 & 47 & 0.83 \\
\hline small trees & 19 & 0.94 & 15 & 0.75 & 14 & 0.67 \\
\hline medium trees & 26 & 3.15 & 22 & 2.77 & 17 & 2.13 \\
\hline large trees & 19 & 6.43 & 13 & 4.17 & 13 & 4.23 \\
\hline \multirow[t]{2}{*}{$\Sigma$} & 88 & 10.95 & 83 & 8.26 & 91 & 7.86 \\
\hline & \multicolumn{2}{|c|}{ Fir 1960} & \multicolumn{2}{|c|}{ Fir 1980} & \multicolumn{2}{|c|}{ Fir 2010} \\
\hline Size category & stems ha ${ }^{-1}$ & $\mathrm{BA}\left(\mathrm{m}^{2} \mathrm{ha}^{-1}\right)$ & stems ha ${ }^{-1}$ & $\mathrm{BA}\left(\mathrm{m}^{2} \mathrm{ha}^{-1}\right)$ & stems ha ${ }^{-1}$ & BA $\left(\mathrm{m}^{2} \mathrm{ha}^{-1}\right)$ \\
\hline pole trees & 185 & 3.26 & 167 & 2.96 & 154 & 2.72 \\
\hline small trees & 78 & 3.81 & 74 & 3.62 & 49 & 2.41 \\
\hline medium trees & 72 & 8.55 & 81 & 9.76 & 59 & 7.36 \\
\hline large trees & 11 & 3.06 & 24 & 6.57 & 32 & 9.55 \\
\hline \multirow[t]{2}{*}{$\Sigma$} & 346 & 18.68 & 346 & 22.90 & 294 & 22.03 \\
\hline & \multicolumn{2}{|c|}{ Spruce 1960} & \multicolumn{2}{|c|}{ Spruce 1980} & \multicolumn{2}{|c|}{ Spruce 2010} \\
\hline Size category & stems ha ${ }^{-1}$ & BA $\left(m^{2} h^{-1}\right)$ & stems ha ${ }^{-1}$ & BA $\left(\mathrm{m}^{2} \mathrm{ha}^{-1}\right)$ & stems ha ${ }^{-1}$ & BA $\left(m^{2} h a^{-1}\right)$ \\
\hline pole trees & 23 & 0.41 & 23 & 0.41 & 27 & 0.48 \\
\hline small trees & 13 & 0.63 & 13 & 0.62 & 11 & 0.54 \\
\hline medium trees & 13 & 1.50 & 16 & 1.97 & 14 & 1.81 \\
\hline large trees & 2 & 0.45 & 5 & 1.25 & 9 & 2.80 \\
\hline \multirow[t]{2}{*}{$\Sigma$} & 50 & 2.98 & 57 & 4.25 & 62 & 5.63 \\
\hline & \multicolumn{2}{|c|}{ Total trees 1960} & \multicolumn{2}{|c|}{ Total trees 1980} & \multicolumn{2}{|c|}{ Total trees 2010} \\
\hline Size category & stems ha ${ }^{-1}$ & $\mathrm{BA}\left(\mathrm{m}^{2} \mathrm{ha}^{-1}\right)$ & stems ha ${ }^{-1}$ & $\mathrm{BA}\left(\mathrm{m}^{2} \mathrm{ha}^{-1}\right)$ & stems ha ${ }^{-1}$ & $\mathrm{BA}\left(\mathrm{m}^{2} \mathrm{ha}^{-1}\right)$ \\
\hline pole trees & 238 & 4.19 & 233 & 4.12 & 243 & 4.30 \\
\hline small trees & 112 & 5.48 & 104 & 5.12 & 79 & 3.87 \\
\hline medium trees & 114 & 13.61 & 122 & 14.84 & 94 & 11.70 \\
\hline large trees & 34 & 10.69 & 43 & 12.43 & 57 & 17.09 \\
\hline$\Sigma$ & 497 & 33.97 & 502 & 36.50 & 473 & 36.96 \\
\hline
\end{tabular}

Table A4. Stem density and basal area (BA) for different size categories in unmanaged stand in Tara Mountain across five decades.

\begin{tabular}{|c|c|c|c|c|c|c|}
\hline \multicolumn{7}{|c|}{ Unmanaged Stand } \\
\hline & \multicolumn{2}{|c|}{ Beech 1960} & \multicolumn{2}{|c|}{ Beech 1980} & \multicolumn{2}{|c|}{ Beech 2010} \\
\hline Size category & stems ha ${ }^{-1}$ & $\mathrm{BA}\left(\mathrm{m}^{2} \mathrm{ha}^{-1}\right)$ & stems ha ${ }^{-1}$ & $\mathrm{BA}\left(\mathrm{m}^{2} \mathrm{ha}^{-1}\right)$ & stems ha ${ }^{-1}$ & $\mathrm{BA}\left(\mathrm{m}^{2} \mathrm{ha}^{-1}\right)$ \\
\hline pole trees & 9 & 0.16 & 4 & 0.07 & 3 & 0.05 \\
\hline small trees & 15 & 0.75 & 12 & 0.57 & 7 & 0.32 \\
\hline medium trees & 15 & 1.70 & 18 & 2.18 & 14 & 1.84 \\
\hline large trees & 8 & 2.56 & 12 & 4.21 & 18 & 6.30 \\
\hline \multirow[t]{2}{*}{$\Sigma$} & 47 & 5.17 & 45 & 7.03 & 42 & 8.52 \\
\hline & \multicolumn{2}{|c|}{ Fir 1960} & \multicolumn{2}{|c|}{ Fir 1980} & \multicolumn{2}{|c|}{ Fir 2010} \\
\hline Size category & stems ha ${ }^{-1}$ & $\mathrm{BA}\left(\mathrm{m}^{2} \mathrm{ha}^{-1}\right)$ & stems ha ${ }^{-1}$ & $\mathrm{BA}\left(\mathrm{m}^{2} \mathrm{ha}^{-1}\right)$ & stems ha ${ }^{-1}$ & $\mathrm{BA}\left(\mathrm{m}^{2} \mathrm{ha}^{-1}\right)$ \\
\hline pole trees & 69 & 1.21 & 83 & 1.47 & 120 & 2.12 \\
\hline small trees & 43 & 2.09 & 44 & 2.14 & 31 & 1.54 \\
\hline medium trees & 65 & 8.24 & 58 & 7.28 & 47 & 5.93 \\
\hline large trees & 28 & 8.32 & 45 & 14.15 & 50 & 16.64 \\
\hline \multirow[t]{2}{*}{$\Sigma$} & 204 & 19.86 & 229 & 25.04 & 248 & 26.23 \\
\hline & \multicolumn{2}{|c|}{ Spruce 1960} & \multicolumn{2}{|c|}{ Spruce 1980} & \multicolumn{2}{|c|}{ Spruce 2010} \\
\hline Size category & stems ha ${ }^{-1}$ & $\mathrm{BA}\left(\mathrm{m}^{2} \mathrm{ha}^{-1}\right)$ & stems ha-1 & $\mathrm{BA}\left(\mathrm{m}^{2} \mathrm{ha}^{-1}\right)$ & stems ha ${ }^{-1}$ & $\mathrm{BA}\left(\mathrm{m}^{2} \mathrm{ha}^{-1}\right)$ \\
\hline pole trees & 7 & 0.12 & 46 & 0.81 & 48 & 0.86 \\
\hline small trees & 9 & 0.46 & 11 & 0.52 & 15 & 0.76 \\
\hline medium trees & 45 & 6.18 & 26 & 3.63 & 21 & 2.67 \\
\hline large trees & 30 & 8.52 & 42 & 13.12 & 47 & 16.28 \\
\hline \multirow[t]{2}{*}{$\Sigma$} & 92 & 15.28 & 125 & 18.08 & 132 & 20.57 \\
\hline & \multicolumn{2}{|c|}{ Total trees 1960} & \multicolumn{2}{|c|}{ Total trees 1980} & \multicolumn{2}{|c|}{ Total trees 2010} \\
\hline Size category & stems ha ${ }^{-1}$ & $\mathrm{BA}\left(\mathrm{m}^{2} \mathrm{ha}^{-1}\right)$ & stems ha ${ }^{-1}$ & $\mathrm{BA}\left(\mathrm{m}^{2} \mathrm{ha}^{-1}\right)$ & stems ha ${ }^{-1}$ & $\mathrm{BA}\left(\mathrm{m}^{2} \mathrm{ha}^{-1}\right)$ \\
\hline pole trees & 85 & 1.50 & 134 & 2.37 & 172 & 3.03 \\
\hline small trees & 68 & 3.35 & 66 & 3.24 & 53 & 2.62 \\
\hline medium trees & 133 & 17.22 & 107 & 13.86 & 84 & 10.72 \\
\hline large trees & 69 & 20.37 & 103 & 32.76 & 119 & 40.34 \\
\hline$\Sigma$ & 355 & 42.43 & 410 & 52.22 & 428 & 56.71 \\
\hline
\end{tabular}


Table A5. The values of the $\mathrm{LTI}_{\mathrm{ba}}$ index for the assessment of basal area dynamics of large trees $>50 \mathrm{~cm}$ $\mathrm{dbh}$, calculated for each tree species and for all species combined at stand level.

\begin{tabular}{cccc}
\hline \multicolumn{3}{c}{ LTI $_{\mathbf{b a}}$ Index Values } \\
\hline & Partly Salvaged Stand & Selection Stand & Unmanaged Stand \\
\hline Beech & -0.07 & -0.34 & 1.46 \\
Fir & 6.12 & 2.12 & 1.00 \\
Spruce & na & 5.19 & 0.91 \\
All species & 0.94 & 0.60 & 0.98 \\
\hline nat available in case when basal area of large trees $>50 \mathrm{~cm}$ dbh was equal to 0 in the first inventory.
\end{tabular}

\section{References}

1. Davis, M.B. Extent and location. In Eastern Old-Growth Forests: Prospects for Rediscovery and Recovery; Davis, M.B., Ed.; Island Press: Washington, DC, USA, 1996; pp. 18-36.

2. Parviainen, J.; Bücking, W.; Vandekerkhove, K.; Schuck, A.; Päivinen, R. Strict forest reserves in Europe: Efforts to enhance biodiversity and research on forests left for free development in Europe (EU-COST-Action E4). Forestry 2000, 73, 107-118. [CrossRef]

3. Global Forest Resource Assessment 2010. Available online: http://www.fao.org/docrep/013/i1757e/i1757e. pdf (accessed on 17 May 2018).

4. Keeton, W.S. Managing for late-successional/old-growth characteristics in northern hardwood-conifer forests. For. Ecol. Manag. 2006, 235, 129-142. [CrossRef]

5. Côté, P.; Tittler, R.; Messier, C.; Kneeshaw, D.D.; Fall, A.; Fortin, M.J. Comparing different forest zoning options for landscape-scale management of the boreal forest: Possible benefits of the TRIAD. For. Ecol. Manag. 2010, 259, 418-427. [CrossRef]

6. Schütz, J.P.; Saniga, M.; Diaci, J.; Vrška, T. Comparing close-to-nature silviculture with processes in pristine forests: Lessons from Central Europe. Ann. For. Sci. 2016, 73, 911-921. [CrossRef]

7. Bauhus, J.; Puettmann, K.; Messier, C. Silviculture for old-growth attributes. For. Ecol. Manag. 2009, 258, 525-537. [CrossRef]

8. Ford, S.E.; Keeton, W.S. Enhanced carbon storage through management for old-growth characteristics in northern hardwood-conifer forests. Ecosphere 2017, 8, e01721. [CrossRef]

9. Kimmins, J.P.; Rempel, R.; Welham, C.; Seely, B.; Rees, V.K. Biophysical sustainability, process-based monitoring and forest ecosystem management decision support systems. For. Chron. 2007, 83, 502-514. [CrossRef]

10. Paillet, Y.; Pernot, C.; Boulanger, V.; Debaive, N.; Fuhr, M.; Gilg, O.; Gosselin, F. Quantifying the recovery of old-growth attributes in forest reserves: A first reference for France. For. Ecol. Manag. 2015, 346, 51-64. [CrossRef]

11. Alessandrini, A.; Biondi, F.; Di, A.; Ziaco, E.; Piovesan, G. Tree size distribution at increasing spatial scales converges to the rotated sigmoid curve in two old-growth beech stands of the Italian Apennines. For. Ecol. Manag. 2011, 262, 1950-1962. [CrossRef]

12. Diaci, J.; Rozenbergar, D.; Anic, I.; Mikac, S.; Saniga, M.; Kucbel, S.; Visnjic, C.; Ballian, D. Structural dynamics and synchronous silver fir decline in mixed old-growth mountain forests in Eastern and Southeastern Europe. Forestry 2011, 84, 479-491. [CrossRef]

13. Motta, R.; Garbarino, M.; Berretti, R.; Meloni, F.; Nosenzo, A.; Vacchiano, G. Development of old-growth characteristics in uneven-aged forests of the Italian Alps. Eur. J. For. Res. 2015, 134, 19-31. [CrossRef]

14. Dieler, J.; Uhl, E.; Biber, P.; Müller, J.; Rötzer, T.; Pretzsch, H. Effect of forest stand management on species composition, structural diversity, and productivity in the temperate zone of Europe. Eur. J. For. Res. 2017, 136, 739-766. [CrossRef]

15. Spies, T.A.; Franklin, J.F. The Diversity and Maintenance of Old-Growth Forests. In Biodiversity in Managed Landscapes: Theory and Practice; Szaro, R.C., Johnston, D., Eds.; Oxford University Press: New York, NY, USA, 1996; pp. 296-314. ISBN 0-19-507958-2. 
16. Gronewold, C.A.; D'Amato, A.W.; Palik, B.J. The influence of cutting cycle and stocking level on the structure and composition of managed old-growth northern hardwoods. For. Ecol. Manag. 2010, 259, 1151-1160. [CrossRef]

17. Hanson, J.J.; Lorimer, C.G.; Halpin, C.R.; Palik, B.J. Ecological forestry in an uneven-aged, late-successional forest: Simulated effects of contrasting treatments on structure and yield. For. Ecol. Manag. 2012, 270, 94-107. [CrossRef]

18. Curtis, R.; Marshall, D.D. Douglas-Fir Rotations-Time for Reappraisal? West. J. Appl. For. 1993, 8, 81-85.

19. Silver, E.J.; D'Amato, A.W.; Fraver, S.; Palik, B.J.; Bradford, J.B. Structure and development of old-growth, unmanaged second-growth, and extended rotation Pinus resinosa forests in Minnesota, USA. For. Ecol. Manag. 2013, 291, 110-118. [CrossRef]

20. Bengtsson, J.; Nilsson, S.G.; Franc, A.; Menozzi, P. Biodiversity, disturbances, ecosystem function and management of european forests. For. Ecol. Manag. 2000, 132, 39-50. [CrossRef]

21. Pretzsch, H. Diversity and productivity in forests: Evidence from long-term experimental plots. In Forest Diversity and Function: Temperate and Boreal Systems; Scherer-Lorenzen, M., Korner, C., Schulze, E.-D., Eds.; Springer: Berlin, Germany, 2005; Volume 176, pp. 41-64. ISBN 978-3-540-22191-3.

22. Fischer, C.; Mölder, A. Trend to increasing structural diversity in German forests: Results from National Forest Inventories 2002 and 2012. Ann. For. Sci. 2017, 74, 80. [CrossRef]

23. Spathelf, P.; Bolte, A.; van der Maaten, E. Is Close-to-Nature Silviculture (CNS) an adequate concept to adapt forests to climate change? Landbauforsch. App. Agric. For. Res. 2015, 65, 161-170. [CrossRef]

24. Bončina, A. History, current status and future prospects of uneven-aged forest management in the Dinaric region: An overview. Forestry 2011, 84, 467-478. [CrossRef]

25. Keren, S.; Diaci, J.; Motta, R.; Govedar, Z. Stand structural complexity of mixed old-growth and adjacent selection forests in the Dinaric Mountains of Bosnia and Herzegovina. For. Ecol. Manag. 2017, 400, 531-541. [CrossRef]

26. Bosela, M.; Tobin, B.; Šeben, V.; Petráš, R.; Larocque, G.R. Different mixtures of Norway spruce, silver fir, and European beech modify competitive interactions in central European mature mixed forests. Can. J. For. Res. 2015, 45, 1577-1586. [CrossRef]

27. Bankovic, S.; Medarevic, M.; Pantic, D.; Petrovic, N.; Sljukic, B.; Obradovic, S. The growing stock of the Republic of Serbia: State and problems. Bull. Fac. For. 2009, 100, 7-30. [CrossRef]

28. Medarević, M.; Banković, S.; Pantić, D.; Obradović, S. Effects of the control method (Goč variety) in selection forest management in western Serbia. Arch. Biol. Sci. 2010, 62, 407-418. [CrossRef]

29. Diaci, J.; Rozenbergar, D.; Fidej, G.; Nagel, T.A. Challenges for uneven-aged silviculture in restoration of post-disturbance forests in central Europe: A synthesis. Forests 2017, 8, 378. [CrossRef]

30. Lang, K.D.; Schulte, L.A.; Guntenspergen, G.R. Windthrow and salvage logging in an old-growth hemlock-northern hardwoods forest. For. Ecol. Manag. 2009, 259, 56-64. [CrossRef]

31. Fidej, G.; Rozman, A.; Diaci, J. Drivers of regeneration dynamics following salvage logging and different silvicultural treatments in windthrow areas in Slovenia. For. Ecol. Manag. 2018, 409, 378-389. [CrossRef]

32. Thorn, S.; Bässler, C.; Svoboda, M.; Müller, J. Effects of natural disturbances and salvage logging on biodiversity—Lessons from the Bohemian Forest. For. Ecol. Manag. 2017, 388, 113-119. [CrossRef]

33. Thorn, S.; Bässler, C.; Brandl, R.; Burton, P.J.; Cahall, R.; Campbell, J.L.; Castro, J.; Choi, C.Y.; Cobb, T.; Donato, D.C.; et al. Impacts of salvage logging on biodiversity: A meta-analysis. J. Appl. Ecol. 2018, 55, 279-289. [CrossRef] [PubMed]

34. Nagel, T.A.; Mikac, S.; Dolinar, M.; Klopcic, M.; Keren, S.; Svoboda, M.; Diaci, J.; Boncina, A.; Paulic, V. The natural disturbance regime in forests of the Dinaric Mountains: A synthesis of evidence. For. Ecol. Manag. 2017, 388, 29-42. [CrossRef]

35. Klopčič, M.; Simončič, T.; Bončina, A. Comparison of regeneration and recruitment of shade-tolerant and light-demanding tree species in mixed uneven-aged forests: Experiences from the Dinaric region. Forestry 2015, 88, 552-563. [CrossRef]

36. Klopčič, M.; Mina, M.; Bugmann, H.; Bončina, A. The prospects of silver fir (Abies alba Mill.) and Norway spruce (Picea abies (L.) Karst) in mixed mountain forests under various management strategies, climate change and high browsing pressure. Eur. J. For. Res. 2017, 136, 1071-1090. [CrossRef]

37. Vasić, M. Tara planina, Šumarska Studija; N. štamparija „Davidović“: Belgrade, Serbia, 1908.

38. Milojković, D. Razvoj gazdovanja i uređivanja šuma GJ Tara. Šumarstvo 1986, 1-2, 11-27. 
39. Obradović, S. Stanje i Razvoj Sastojina Bukve, jele i Smrče Prašumskog Porekla u Srbiji kao Osnov za Planiranje i obezbeđivanje Prirodi Bliskog Gazdovanja. Ph.D. Thesis, University of Belgrade, Belgrade, Serbia, 2015.

40. Pantic, D.; Medarevic, M.; Bankovic, S.; Obradovic, S.; Sljukic, B.; Pesic, B. Structural, production and dynamic characteristics of the strict forest reserve "Račanska šljivovica" on mt. Tara. Bull. Fac. For. 2011, 93-114. [CrossRef]

41. Bončina, A.; Čavlović, J.; Čurović, M.; Govedar, Z.; Klopčič, M.; Medarević, M. A comparative analysis of recent changes in Dinaric uneven-aged forests of the NW Balkans. Forestry 2014, 87, 71-84. [CrossRef]

42. Janowiak, M.K.; Nagel, L.M.; Webster, C.R. Spatial Scale and Stand Structure in Northern Hardwood Forests: Implications for Quantifying Diameter Distributions. For. Sci. 2008, 54, 497-506.

43. Burnham, K.P.; Anderson, D.R. Model Selection and Multimodel Inference: A Practical Information-Theoretic Approach; Springer: New York, NY, USA, 2002; ISBN 0-387-95364-7.

44. Zenner, E.K.; Peck, J.L.E. Floating neighborhoods reveal contribution of individual trees to high sub-stand scale heterogeneity. For. Ecol. Manag. 2018, 412, 29-40. [CrossRef]

45. Lafond, V.; Cordonnier, T.; De Coligny, F.; Courbaud, B. Reconstructing harvesting diameter distribution from aggregate data. Ann. For. Sci. 2012, 69, 235-243. [CrossRef]

46. Klopcic, M.; Boncina, A. Stand dynamics of silver fir (Abies alba Mill.)-European beech (Fagus sylvatica L.) forests during the past century: A decline of silver fir? Forestry 2011, 84, 259-271. [CrossRef]

47. Jaroszewicz, B.; Bobiec, A.; Eycott, A.E. Lack of demographic equilibrium indicates natural, large-scale forest dynamics, not a problematic forest conservation policy-A reply to Brzeziecki et al. J. Veg. Sci. 2017, 28, 218-222. [CrossRef]

48. Fassnacht, K.S.; Bronson, D.R.; Palik, B.J.; Amato, A.W.D.; Lorimer, C.G.; Martin, K.J. Accelerating the Development of Old-Growth Characteristics in Second-Growth Northern Hardwoods; General Technical Report; U.S. Depoartment of Agriculture, Forest Service, Northern Research Station: Newtown Square, PA, USA, 2015.

49. Brzeziecki, B.; Pommerening, A.; Miścicki, S.; Drozdowski, S.; Zybura, H. A common lack of demographic equilibrium among tree species in Bialowieża National Park (NE Poland): Evidence from long-term plots. J. Veg. Sci. 2016, 27, 460-469. [CrossRef]

50. Dobrowolska, D.; Niemczyk, M.; Olszowska, G. The influence of stand structure on European yew Taxus baccata populations in its natural habitats in central Poland. Pol. J. Ecol. 2017, 65, 369-384. [CrossRef]

51. Čavlović, J.; Božić, M.; Bončina, A. Stand structure of an uneven-aged fir-beech forest with an irregular diameter structure: Modeling the development of the Belevine forest, Croatia. Eur. J. For. Res. 2006, 125, 325-333. [CrossRef]

52. Petritan, I.C.; Commarmot, B.; Hobi, M.L.; Petritan, A.M.; Bigler, C.; Abrudan, I.V.; Rigling, A. Structural patterns of beech and silver fir suggest stability and resilience of the virgin forest Sinca in the Southern Carpathians, Romania. For. Ecol. Manag. 2015, 356, 184-195. [CrossRef]

53. O'Hara, K.L.; Gersonde, R.F. Stocking control concepts in uneven-aged silviculture. Forestry 2004, 77, 131-143. [CrossRef]

54. Schütz, J.P. Die Plenterung und ihre Unterschiedlichen Formen Skript zu Vorlesung Waldbau II und Waldbau IV; ETH Zürich: Zürich, Switzerland, 2002.

55. Goodburn, J.M.; Lorimer, C.G. Population structure in old-growth and managed northern hardwoods: An examination of the balanced diameter distribution concept. For. Ecol. Manag. 1999, 118, 11-29. [CrossRef]

56. Motta, R.; Berretti, R.; Castagneri, D.; Dukić, V.; Garbarino, M.; Govedar, Z.; Lingua, E.; Maunaga, Z.; Meloni, F. Toward a definition of the range of variability of central European mixed Fagus-Abies-Picea forests: The nearly steady-state forest of Lom (Bosnia and Herzegovina). Can. J. For. Res. 2011, 41, 1871-1884. [CrossRef]

57. Schwartz, J.W.; Nagel, L.M.; Webster, C.R. Effects of uneven-aged management on diameter distribution and species composition of northern hardwoods in Upper Michigan. For. Ecol. Manag. 2005, 211, 356-370. [CrossRef]

58. O'Hara, K.L.; Hasenauer, H.; Kindermann, G. Sustainability in multi-aged stands: An analysis of long-term plenter systems. Forestry 2007, 80, 163-181. [CrossRef]

59. Pretzsch, H.; Rötzer, T. Indicating Forest Ecosystem and Stand Productivity: From Deductive to Inductive Concepts. In Ecological Forest Management Handbook, Series of Applied Ecology and Environmental Management; Laroque, G.R., Ed.; CRC Press Taylor \& Francis Group: Boca Raton, FL, USA, 2016; pp. 415-444. 
60. Jaloviar, P.; Saniga, M.; Kucbel, S.; Pittner, J.; Vencurik, J.; Dovciak, M. Seven decades of change in a European old-growth forest following a stand-replacing wind disturbance: A long-term case study. For. Ecol. Manag. 2017, 399, 197-205. [CrossRef]

61. Keren, S.; Motta, R.; Govedar, Z.; Lucic, R.; Medarevic, M.; Diaci, J. Comparative structural dynamics of the Janj mixed old-growth mountain forest in Bosnia and Herzegovina: Are conifers in a long-term decline? Forests 2014, 5, 1243-1266. [CrossRef]

62. Marinšek, A.; Diaci, J. A comparison of structural characteristics and ecological factors between forest reserves and managed silver fir: Norway spruce forests in Slovenia. Ekológia (Bratislava) 2011, 30, 51-66. [CrossRef]

63. Szwagrzyk, J.; Szewczyk, J.; Maciejewski, Z. Shade-tolerant tree species from temperate forests differ in their competitive abilities: A case study from Roztocze, south-eastern Poland. For. Ecol. Manag. 2012, 282, 28-35. [CrossRef]

64. Vrška, T.; Adam, D.; Hort, L.; Kolář, T.; Janík, D. European beech (Fagus sylvatica L.) and silver fir (Abies alba Mill.) rotation in the Carpathians - A developmental cycle or a linear trend induced by man? For. Ecol. Manag. 2009, 258, 347-356. [CrossRef]

65. Dobrowolska, D.; Bončina, A.; Klumpp, R. Ecology and silviculture of silver fir (Abies alba Mill.): A review. J. For. Res. 2017, 22, 326-335. [CrossRef]

66. Keren, S.; Diaci, J. Comparing the quantity and structure of deadwood in selection managed and old-growth forests in South-East Europe. Forests 2018, 9, 76. [CrossRef]

67. Motta, R.; Garbarino, M.; Berretti, R.; Bjelanovic, I.; Borgogno Mondino, E.; Čurović, M.; Keren, S.; Meloni, F.; Nosenzo, A. Structure, spatio-temporal dynamics and disturbance regime of the mixed beech-silver fir-Norway spruce old-growth forest of Biogradska Gora (Montenegro). Plant Biosyst. 2015, 149, 966-975. [CrossRef]

68. Marage, D.; Lemperiere, G. The management of snags: A comparison in managed and unmanaged ancient forests of the Southern French Alps. Ann. For. Sci. 2005, 62, 135-142. [CrossRef]

69. Mason, F.; Nardi, G.; Whitmore, D. Recherches sur la restauration des habitats du bois mort: L'exemple du LIFE “Bosco della Fontana” (Italie). In Bois Mort et à Cavités, Une clé Pour Des Forêts Vivantes; Vallauri, D., André, J., Dodelin, B., Eynard-Machet, R., Rambaud, D., Eds.; Tec \& Doc: Paris, France, 2005; pp. $285-291$. 